\title{
Anthropometric profiles of children with congenital heart disease
}

\author{
Damayanti R. Sjarif, ${ }^{1}$ Shirley L. Anggriawan, ${ }^{2}$ Sukman T. Putra, ${ }^{2}$ Mulyadi M. Djer, ${ }^{2}$ \\ ${ }^{1}$ Division of Pediatric Nutrition and Metabolic Disease, Department of Child Health, University of Indonesia, Jakarta, Indonesia \\ ${ }^{2}$ Division of Pediatric Cardiology, Department of Child Health, University of Indonesia, Jakarta, Indonesia
}

\begin{abstract}
Abstrak
Latar belakang: Kekurangan gizi merupakan penyebab umum morbiditas pada anak dengan penyakit jantung bawaan (PJB). Data dari negara berkembang memperlihatkan prevalensi malnutrisi penderita dengan PJB sebelum dioperasi mencapai 45\%. Penelitian ini bertujuan untuk mengetahui profil anhropometrik dan prevalensi kekurangan gizi pada anak dengan PJB dengan melakukan pengukuran anthropometrik.

Metode: Penelitian ini merupakan penelitian dengan rancang bangun cross sectional pada anak berusia 0-2 tahun dengan PJB di RSCM. Pengukuran antropometri (berat badan, panjang badan, lingkar kepala) dilakukan pada seluruh pasien. Kekurangan gizi, failure to thrive/FTT, perawakan pendek, mikrosefali dinilai dengan menggunakan rekomendasi WHO tahun 2006, berupa perhitungan z-skor BB/PB, BB/U di 2 titik, PB/U dan LK/U <-2 SD.

Hasil: Total subyek dalam penelitian ini berjumlah 95 orang, 73 orang dengan asianotik dan 22 orang dengan PJB sianotik. Prevalensi kekurangan gizi sebesar 51,1\% dengan 22,3\% diantaranya adalah gizi buruk. FTT terdapat pada $64,9 \%$, perawakan pendek pada 49,5\% dan mikrosefali pada 37\% pasien. FTT ditemukan lebih banyak pada pasien dengan lesi asianotik (72,2\%) dibandingkan dengan lesi sianotik (42,9). Pada lesi asianotik, berat badan lebih dipengaruhi daripada panjang badan (72,2\% dengan 49,3\%). Pasien dengan lesi sianotik, berat dan panjang badan akan dipengaruhi secara seimbang (42,9\% dengan 54.5\%). Konsultasi diet diberikan kepada pasien dengan kekurangan gizi. Terapi obat-obatan, intervensi transkateter atau bedah diindikasikan pada pasien tertentu.

Kesimpulan: Prevalensi FTT lebih tinggi dibandingkan dengan kekurangan gizi pada anak dengan kelainan jantung kongenital. FTT ditemukan lebih banyak pada pasien dengan lesi asianotik. Pada lesi asianotik, berat badan lebih dipengaruhi daripada panjang badan. Pada lesi asianotik, berat badan lebih dipengaruhi daripada panjang badan. (Med J Indones 2011; 20:40-5)
\end{abstract}

\begin{abstract}
Background: Undernutrition is a common cause of morbidity in children with CHD. Previous data from developing country showed prevalence of preoperative undernutrition in children with CHD was up to 45\%. The aim of this study are to determine the anthropometric profiles and prevalence of undernutrition in children with CHD by using the anthropometric measurement.

Methods: A cross-sectional study was carried out in children aged 0-2 years old with CHD in Cipto Mangunkusumo hospital. All patients underwent an anthropometric evaluation (weight, length and head circumference) at presentation. Undernutrition, failure to thrive /FTT, short stature and microcephaly were determined according to WHO, weight-forlength, weight-for-age at 2 points, length-for-age, head circumference-for-age z-score <-2SD accordingly.

Results: We had total of 95 patients, 73 patients with acyanotic and 22 patients with cyanotic lesions. Prevalence of undernutrition in CHD was 51.1\%, with $22.3 \%$ severe undernutrition. FTT was found in $64.9 \%$, short stature in $49.5 \%$ and microcephaly in $37 \%$ patients. FTT was found higher in acyanotic $(72.2 \%)$ compared to cyanotic lesions (42.9\%). In acyanotic, weight was affected more than length (72.2\% vs $49.3 \%)$. In cyanotic, weight and length affected equally (42.9\% vs 54.5\%). Diet counseling were done in patients with undernutrition. Medicines, transcatheter or surgery intervention were indicated in selected patients.

Conclusions: Prevalence of FTT was higher than undernutrition in children with CHD. FTT was found higher in acyanotic lesions. In acyanotic, weight was affected more than length. In cyanotic, weight and length affected equally. (Med J Indones 2011; 20:40-5)
\end{abstract}

Key words: congenital heart disease, failure to thrive, short stature, undernutrition

Undernutrition is one of the malnutrition problem in Indonesia. Data from National Socioeconomic Survey (Survei Social Ekonomi Nasional/SUSENAS) 2007 showed the prevalence of children under 5 years who had underweight is $18.4 \%$. Indonesia's MDG (Millenium Developmental Goal) in 2015 is to reduce the prevalence of severe underweight to $3.3 \%$ and moderate underweight to $18 \%{ }^{1}$

Correspondence email to: flowersla1979@yahoo.com
Undernutrition is a common cause of morbidity in children with congenital heart disease (CHD). Undernutrition can be caused by inadequate nutritional intake or absorption, excessive energy expenditure, frequent respiratory infections, limitation of growth potential and genetic syndromes. Previous data from developing country showed prevalence of pre operative undernutrition in children with CHD was up to $45 \%{ }^{2,3}$ 
At birth, the weight and length of children with CHD are typically normal or close to normal and APGAR scores are generally high. ${ }^{4}$

Cyanotic patients are affected in growth, depending on the severity of tissue hypoxemia and on the degree of physiological adaptation. Weight and height are affected equally in cyanotic patients. Acyanotic lesions, especially in combination with septal defect, left to right shunt, will affect weight more than height. Acyanotic lesions were related to acute malnutrition, whereas cyanotic lesions were related to chronic malnutrition. ${ }^{4,5}$

The aims of this study are to determine the anthropometric profiles and prevalence of undernutrition in children with CHD by using the anthropometric measurement. Those measurements are useful in early detection of CHD and assessing the prognosis of the basic defects and their complications.

\section{METHODS}

A cross-sectional study was carried out in children aged 0-2 years old with CHD who had consultation in our outpatient clinic, cardiology division, department of child health in Cipto Mangunkusumo Hospital, Jakarta. This study was conducted from February to August 2009. Children should meet the inclusion criteria for age, no definitive or palliative treatment were given and filled up the informed consent. Consent was obtained in accordance with the Ethical Committee Cipto Mangunkusumo Hospital-University of Indonesia.

All patients underwent an anthropometric evaluation (weight, length and head circumference/HC) at presentation. Echocardiography was done on the same day to determine the type of CHD.

Anthropometric data were analyzed using WHO anthro 2006 (software for assessing growth and development of the world's children). Undernutrition, failure to thrive, short stature and microcephaly were determined according to weight-for-length, weight-for-age at 2 points, length-for-age and head circumference-for-age z-score $<-2$ SD accordingly. ${ }^{6}$

\section{RESULTS}

We had total of 95 patients, consisted of 52 (54.7\%) male and 43 (45.3\%) female with age of gestation ranged from 31 to 40 weeks. Their ages ranged from 0.49 to 24 months old with $12.8 \%$ of them had low birth weight.
Table 1. Age and anthropometric measurement (birth weight, length, and weight) in children with CHD

\begin{tabular}{lcc}
\hline \multicolumn{1}{c}{ Variable } & Minimum-maximum & Median \\
\hline Age (month) & $0.49-24$ & 7,1 \\
Birth weight (gram) & $1300-4000$ & 3100 \\
Birth length (cm) & $30-54$ & 49 \\
Weight (gram) & $2415-13740$ & 5750 \\
\hline
\end{tabular}

Table 2. Anthropometric measurement (length, head circumference, weight/length, weight/age, length/age, HC/ age z-score) in children with CHD

\begin{tabular}{lc}
\hline \multicolumn{1}{c}{ Variable } & Mean \pm Standar Deviation (SD) \\
\hline Length $(\mathrm{cm})$ & $64.93 \pm 8.92$ \\
Head circumference/HC $(\mathrm{cm})$ & $41.16 \pm 3.94$ \\
weight/length z-score & $-1.93 \pm 1.57$ \\
weight/age z-score & $-2.69 \pm 1.51$ \\
length/age z-score & $-2.09 \pm 1.47$ \\
HC/age z-score & $-1.67 \pm 1.52$ \\
\hline
\end{tabular}

$\mathrm{HC}=$ head circumference; $\mathrm{SD}=$ standard deviation

Table 3. Prevalence of undernutrition, failure to thrive, short stature and microcephaly in children with CHD

\begin{tabular}{lcl}
\hline \multicolumn{1}{c}{ Variable } & $<-$ 2 SD (\%, 95\%CI) & $<-3$ SD (\%,95\% CI) \\
\hline weight/length z-score & $51.1 \%(40.4 \%-61.7 \%)$ & $22.3 \%(13.4 \%-31.3 \%)$ \\
weight/age z-score & $64.9 \%(54.7 \%-75.1 \%)$ & $46.8 \%(36.2 \%-57.4 \%)$ \\
length/age z-score & $49.5 \%(38.9 \%-60.1 \%)$ & $30.5 \%(20.7 \%-40.3 \%)$ \\
HC/age z-score & $37 \%(26.5 \%-47.4 \%)$ & $21,7 \%(12.8 \%-30.7 \%)$ \\
\hline
\end{tabular}

$\mathrm{HC}=$ head circumference; $\mathrm{SD}=$ standard deviation; $\mathrm{CI}=$ confidence interval

Acyanotic heart disease was present in 73 (76.8\%) of all patients whereas cyanotic heart disease affected 22 (23.2\%). The most common diagnoses were ventricular septal defect/VSD (23.2\%), patent ductus arteriosus/PDA (13.7\%), tetralogy of fallot/ TOF (12.6\%), atrial septal defect/ASD (7.4\%) and valvular pulmonary stenosis (6.3\%). Two or more CHD were found in $27.8 \%$ patients. Study done in our institution (1983-1992) showed the same results, with $76.7 \%$ acyanotic and $23.3 \%$ cyanotic CHD. ${ }^{7}$

Birth weight/age z-score < -2SD was 12.8\% (95\% CI 5.5\%-20\%), <-3SD 9.6\% (95\% CI 3.1\%-16.1\%), mean $-0.76 \pm 1.31$. Weight/age $\mathrm{z}$-score $<-2 \mathrm{SD}$ was $64.9 \%$ (95\% CI 54.7\%-75.1\%), < -3SD was 46.8\% (95\% CI $36.2 \%-57.4 \%)$, and mean $-2.69 \pm 1.51$.

Birth length/age z-score <-2SD was 14.9\% (95\% CI 6.1\%-23.6\%), <-3 SD 5.4\% (95\% CI 0-11.2\%), mean $-0.76 \pm 1.38$. Length/age age $\mathrm{z}$-score $<-2 \mathrm{SD}$ was $49.5 \%$ (95\% CI 38.9\%-60.1\%), <-3SD was 30.5\% (95\% CI 20.7\%-40.3\%) and mean $-2.09 \pm 1.47$. 


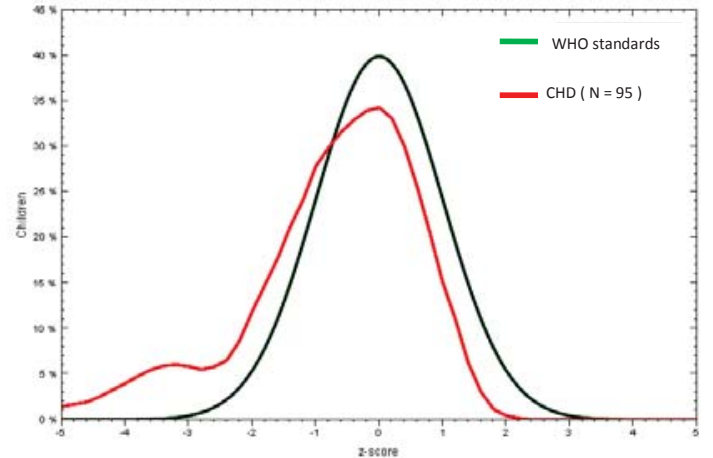

Figure 1. Birth weight/age z-score

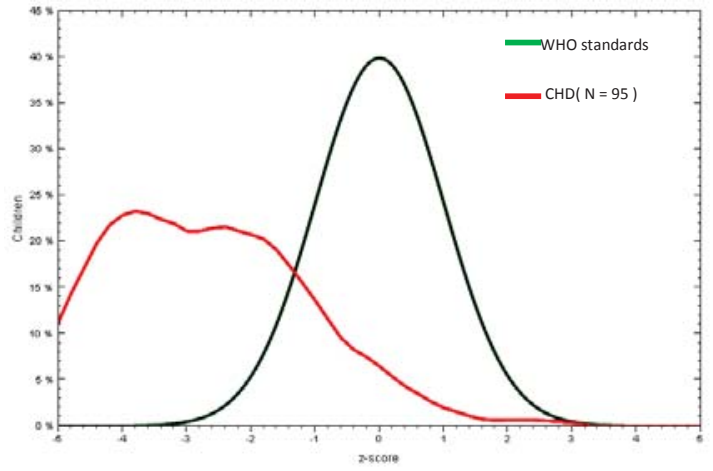

Figure 2. weight/age z-score children with CHD

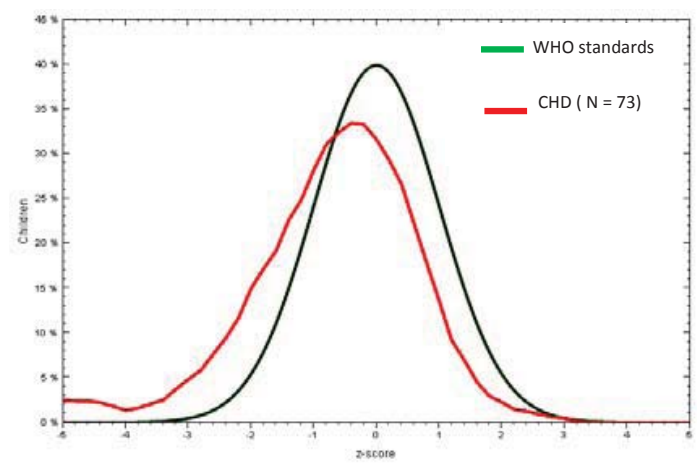

Figure 3. Birth length/age z-score

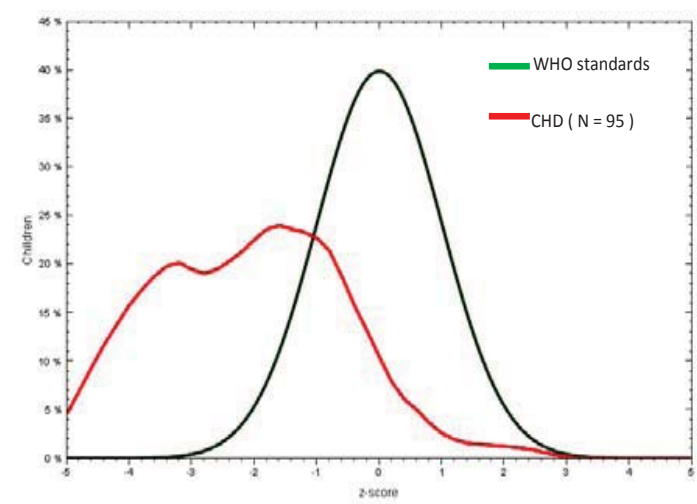

Figure 4. Length/age z-score children with CHD

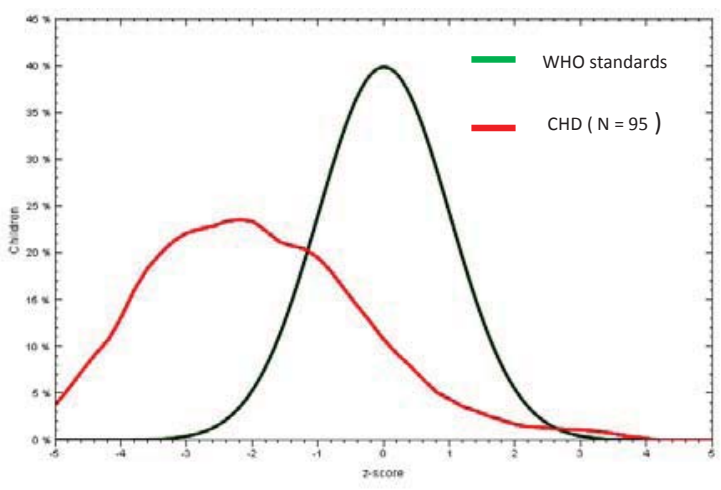

Figure 5. Weight/length z-score children with CHD
Weight/length z-score <-2SD was 51.1\% (95\% CI 40.4\%-61.7\%), <-3SD was 22.3\% (95\% CI 13.4\%$31.3 \%)$ and mean $-1.93 \pm 1.57$.

In acyanotic, weight/length z-score < -2SD was 54.2\% (95\% CI 42\%-66.4\%), <-3SD was 22.2\% (95\% CI $11.9 \%-32.5 \%)$, mean $-1.99 \pm 1.47$. In cyanotic, weight/ length z-score <-2SD was 40.9\% (95\% CI 18.1\%-
$63.7 \%),<-3 S D$ was $22.7 \%$ (95\% CI 2.9\%-42.5\%) and mean $-1.74 \pm 1.88$.

In acyanotic, weight/age z-score <-2SD was 72.2\% (95\% CI 61.2-83.3\%), <-3SD was 50\% (95\% CI 37.8\%-62.2\%), mean $-2.76 \pm 1.46$. In cyanotic, weigth/age z-score $<-2 S D$ was $42.9 \%$ (95\% CI 19.3-66.4\%), <-3SD was 33.3\% (95\% CI 10.8\%-55.9\%) with mean $-2.38 \pm 1.47$. 


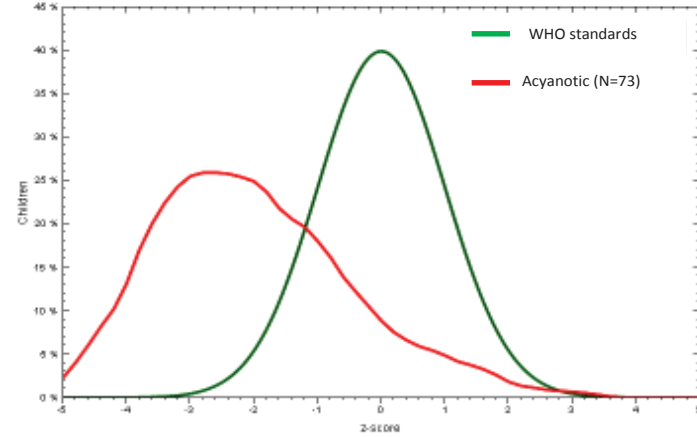

Figure 6. Weight/length z-score acyanotic

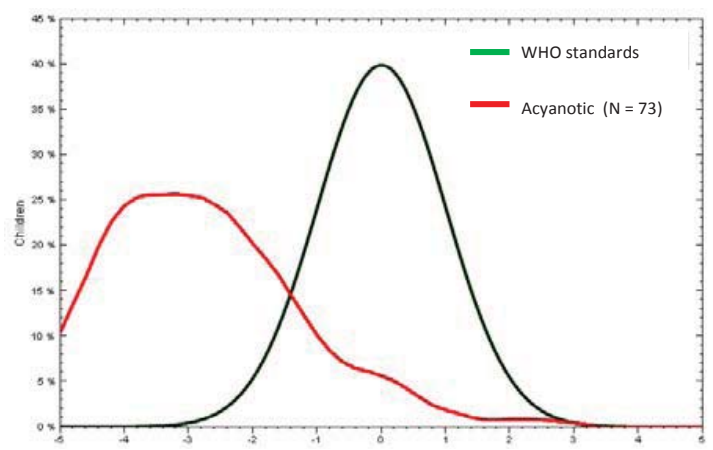

Figure 8. Weight/age z-score acyanotic

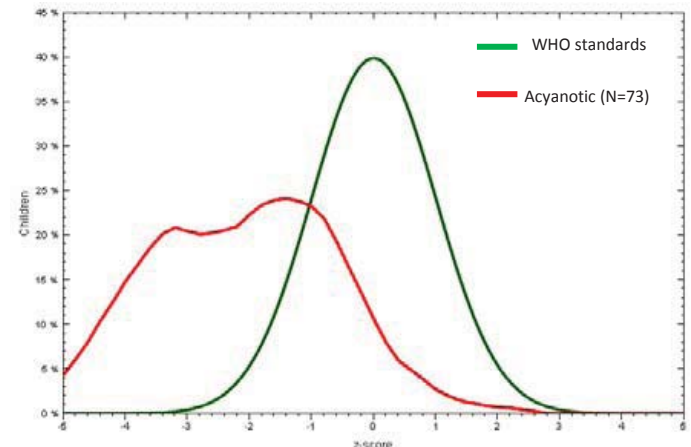

Figure 10. Length/age z-score acyanotic

In acyanotic, Length/age z-score <-2SD was $49.3 \%$ (95\% CI 37.2\%-61.5\%), <-3SD was 30.1\% (95\% CI 18.9\%$41.3 \%)$, mean $-2.1 \pm 1.43$. In cyanotic, length/age z-score $<-2$ SD was $54.5 \%$ (95\% CI 31.5\%-77.6\%), <-3SD was $36.4 \%$ (95\% CI 14\%-58.7\%) and mean -2.25 \pm 1.43 .

Head circumference/age z-score <-2SD was 37\% (95\% CI $26.5 \%-47.4 \%),<-3$ SD was $21.7 \%$ (95\% CI $12.8 \%$ $30.7 \%$ ) and mean $-1.67 \pm 1.52$.

Pulmonary hypertension was noted in 12 children, pericardial effusion in 1 children, and 4 children with VSD and aortic valve prolaps. Down syndrome was present in $9.5 \%$ and congenital Rubella in $4.2 \%$ children. Diet counseling were done in patients with undernutrition. Medicines, transcatheter or surgery intervention were indicated in selected patients.

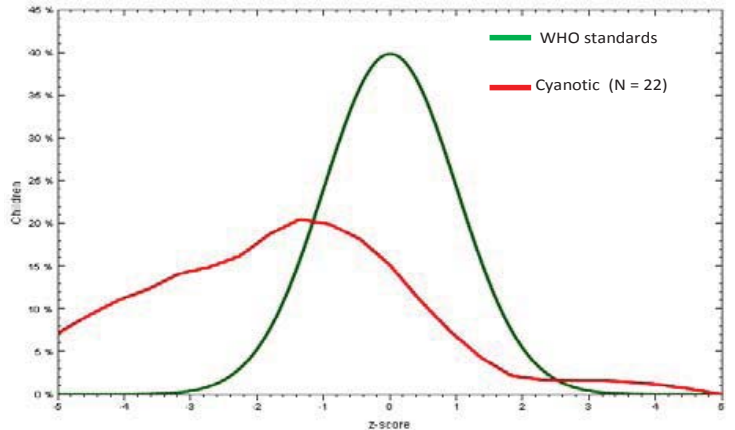

Figure 7. Weight/length z-score cyanotic CHD

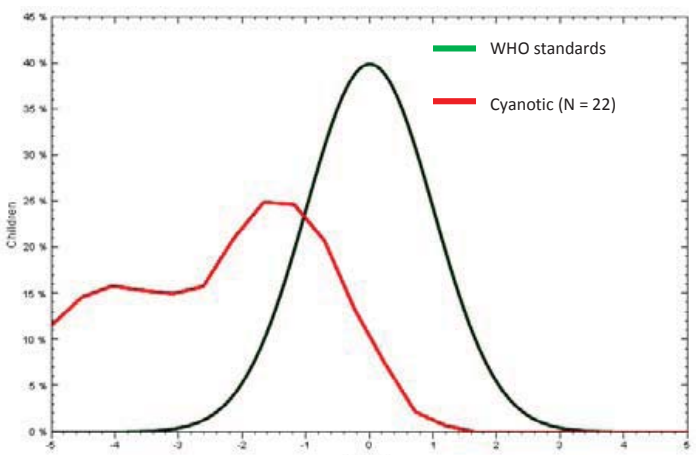

Figure 9. Weight/age z-score cyanotic CHD

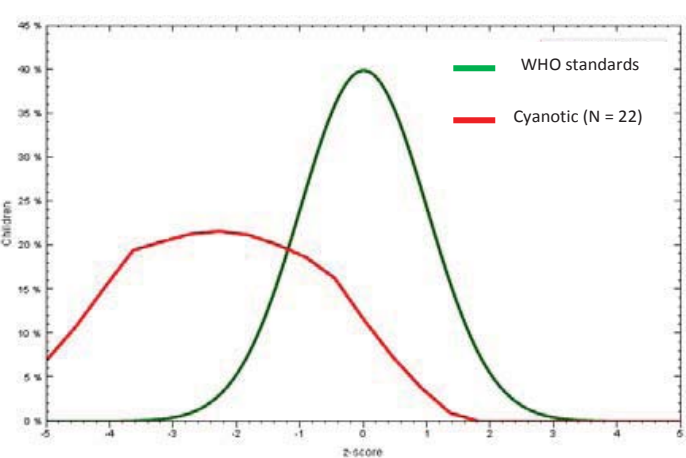

Figure 11. Length/age z-score cyanotic CHD

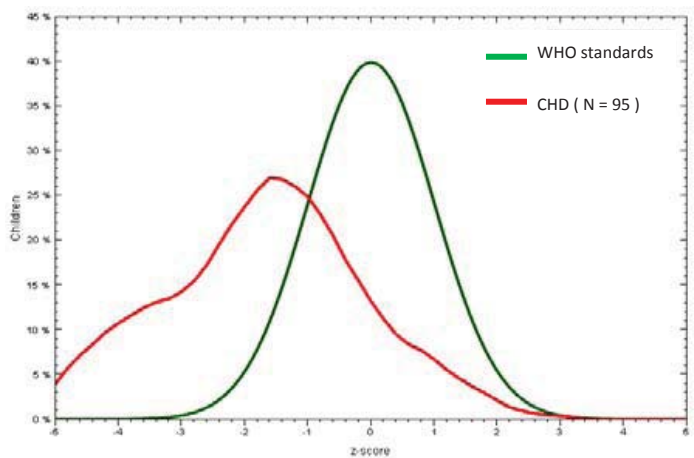

Figure 12. Head circumference/age z-score in children with $C H D$ 


\section{DISCUSSION}

In figure 1 and 2, we can determine failure to thrive, which weight/age z-score at 2 points crossed downward 2 standard deviation. Mean birth weight/age was -0.76 \pm 1.31 and mean weight/age was $-2.69 \pm 1.51$.

Prevalence of undernutrition in CHD children was $51.1 \%$, with $22.3 \%$ severe malnutrition (figure 5 .). This prevalence was slightly high compared to study done by Vaidyanathan in India (45\%). Since the prevalence of FTT (64.9\%) was higher than undernutrition (51.1\%), monitoring anthropometric measurement in children should be observed since birth using KMS
(Kartu Menuju Sehat). If FTT is present, it can be an important point for parents, relatives and doctor to be aware about CHD, especially acyanotic type. It can be also a good point to refer the children to a better facility for diagnostic and further management. We gave examples of our patient as described below.

One of our patients, A.N, 2 years old boy with acyanotic CHD (large Patent Ductus Arteriousus/ PDA). His current weight is 8040 gram and birth weight of 2700 gram. We computed the weight/age z-score at 2 points, which revealed significant decreased of z-score to -3.59 at 2 years old. (figure 13.)

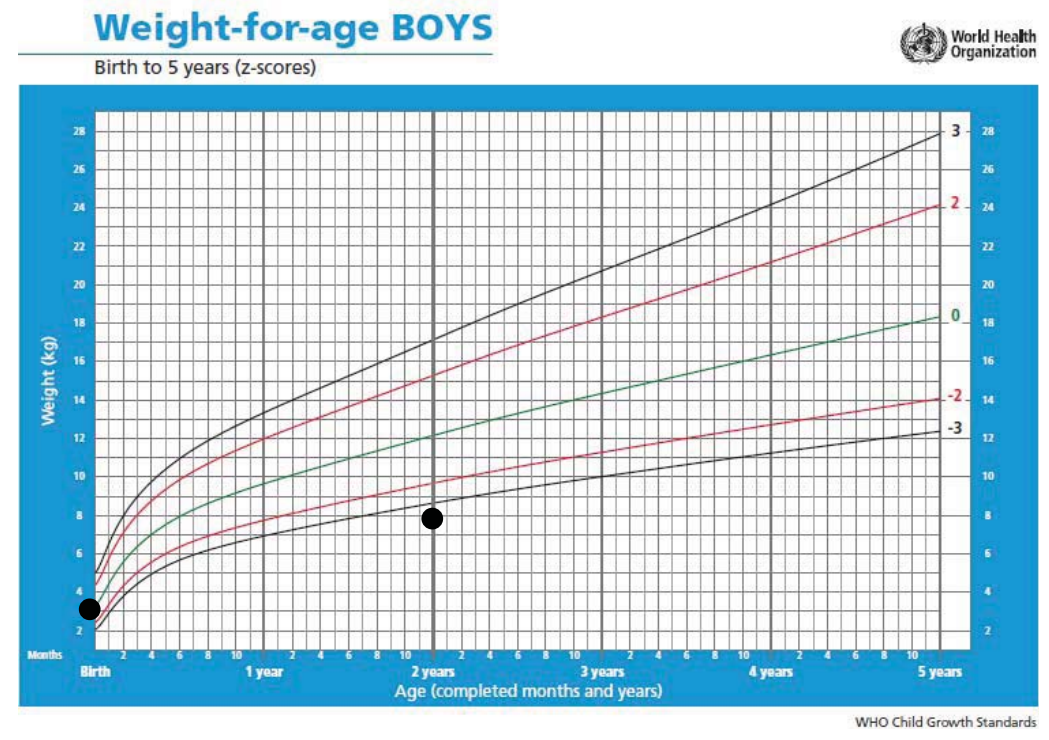

Figure 13. Weight-for-age z-score (birth to 5 years)

Figure 6 and 7 showed the prevalence of undernutrition is higher in acyanotic CHD $(54,2 \%)$ compared to cyanotic CHD (40.9\%). Figure 2, 8 and 9 showed failure to thrive was found in $64.9 \%$ children with CHD, it was noted higher in acyanotic (72.2\%) compared to cyanotic lesions (42.9\%).

Undernutrition in acyanotic was higher compared to cyanotic lesions. It can be due to present of leftto right shunt that caused decrease in cardiac output goes to the systemic. Patients with congestive failure due to left-to-right intracardiac shunting, particularly those with right-heart failure and elevation of systemic venous pressure, may develop edema of intestinal wall and mucosal surfaces that leads to impaired nutrient absorption and lymphatic drainage.

Other factors contributing to low caloric intake and increased energy requirement include feeding difficulties associated with tachypnea, fatigue, respiratory infections in patients with congestive heart failure (CHF). Restricton of fluid intake as treatment for CHF may have the unintended effect of excessive caloric restriction. Diuretic therapy may produce anorexia from metabolic alkalosis and hypokalemia or may inhibit effective protein anabolism., ${ }^{8,9}$

Prevalence of short stature was $49.5 \%$. If we compared figure 8 and 10, in acyanotic lesions, weight was affected more than length (72.2\% vs $49.3 \%)$. Weight was also more affected than length in studies done by Angelov (1980), Poskitt (1987), Salzer (1989), Thommessen (1991), and Mitchell (1994)..$^{5,10,11}$ A Scottish report from Mitchell (1994) also documented levels below the third percentile for weight and height in, respectively, 52\% and $37 \%$ of the subjects under study. ${ }^{11}$ This finding also same with the result of study done by Madiyono (1987) which included 46 patients aged 1-5 years old 
with VSD in Cipto Mangunkusumo hospital. ${ }^{12}$ If we compared figure 9 and 11, in cyanotic lesions, weight and length affected equally (42.9\% vs 54.5 ).

Limitations of this study, possible risk factors such as number of family members, monthly income, mid-parental height, presence of congestive heart failure, pulmonary hypertension were not analyzed in this study.

In conclusion, prevalence of FTT was higher than undernutrition in children with CHD. FTT was found higher in acyanotic lesions. In acyanotic, weight was affected more than length. In cyanotic, weight and length affected equally

\section{Acknowledgments}

This study is funded by Hibah Penelitian Strategis Nasional 2009.

\section{REFERENCES}

1. Direktorat Kesehatan dan Gizi Masyarakat Kedeputian Sumber Daya Manusia dan Kebudayaan Badan Perencanaan Pembangunan Nasional. Pengembangan Database Pembangunan Bidang Kesehatan dan Gizi Masyarakat 2009.

2. Vaidyanathan B, Roth SJ, Rao SG, Gauvreau K, Shivaprakashi $\mathrm{K}$, Kumar RK. Outcome of ventricular septal defect repair in a developing country. J Pediatr. 2002;140:736-41.

3. Vaidyanathan B, Roth SJ, Gauvreau K, Shivaprakasha K, Rao SG, Kumar RK. Somatic growth after Ventricular Septal Defect in malnourished infants. J Pediatr. 2006;149:205-9.
4. Da Silva VM, de Oliveira Lopes MV, de Araujo TL. Growth and nutritional status of children with congenital heart disease. J Cardiovasc Nurs. 2007;22(5):390-6.

5. Staebel OD. Malnutrition in Belgian children with congenital heart disease on admission to hospital. J Clin Nurs. 2000;9:784-91.

6. WHO Multicentre Growth Reference Study Group. WHO Child Growth Standards: Length/height-for-age, Weightfor-age, Weight-for-length, Weight-for-height and Body mass index-for-age : Methods and Development. Geneva: World Health Organization, 2006.

7. Sastroasmoro S, Madiyono B. Epidemiologi dan etiologi penyakit jantung bawaan. In: Sastroasmoro S, Madiyono B, (eds). Buku Ajar Kardiologi Anak. Ikatan Dokter Anak Indonesia. Jakarta: 1994. p.166-7.

8. Kaine SF, Reid BS. Nutrition and growth in congenital heart disease. In : Garson A, Bricker JT, Fisher DJ, Neish SR, penyunting. The Science and Practice of Pediatric Cardiology. $2^{\text {nd }}$ ed. Baltimore : Williams \& Wilkins 1998. p. 2301-6

9. Penny ME. Protein-energy malnutrition : pathophysiology, clinical consequences, and treatment. In : Duggan C, Watkins JB, Walker WA, penyunting. Nutrition in Pediatrics. $4^{\text {th }}$ ed. Hamilton: BC Decker Inc, 2008. p. 127-41.

10. Mitchell IM, Logan RW, Pollock JCS, Jamieson. Nutritional Status of Children with Congenital Heart Disease. Br Heart J 1995;73:277-83.

11. Mitchell I.M, Davies P.S.W., Day J.M.E., Pollock J.C.S, Jamieson M.P.G. Energy expenditure in children with congenital heart disease, before and after surgery. J Thor Cardiovasc Surg. 1994;107:374-80.

12. Madiyono B, Soelaoman EJ, Oesma IN, Sastroasmoro S. Physical growth of children with ventricular septal defect. Paediatr Indones. 1994;34:16-25. 